\title{
The Escalation of Trump: Stormfront and the 2016 Election
}

\section{Dianne Dentice ${ }^{1}$}

This paper explores the 2016 presidential election through the lens of Stormfront, the first Internet Web site dedicated to individuals who self-identify as white nationalists. Since 1995, the year of its inception, Stormfront has grown to 318,688 members worldwide. At the end of December 2016, the site contained 944,557 threads and $12,206,400$ individual posts. The Internet site is a rich source of material that represents attitudes of a segment of the white population who believe that they are marginalized due to multiculturalism and immigration patterns from Latin America along with countries from the Middle East, Asia, and Africa. Findings indicate that not all people who are affiliated with Stormfront supported Donald Trump's candidacy and subsequent election. Some discussants hoped, that if elected, he would shake up Washington and many supported his opinions about women, minority populations, and immigration. One of the key factors in less than overwhelming support among white nationalists who populate the online world of Stormfront was distrust based on his Jewish connections through his daughter Ivanka and son in law, Jared Kushner. [Article copies available for a fee from The Transformative Studies Institute.E-mail address: journal@transformativestudies.org Website: http://www.transformativestudies.org 02018 by The Transformative Studies Institute. All rights reserved.]

KEYWORDS: Donald Trump, Stormfront, White Nationalism, 2016 Election.

\footnotetext{
${ }^{1}$ Dianne Dentice, Ph.D., recieved her Doctorate in Sociology from Texas Woman's University in Denton, Texas in August 2006. She spent seven years doing field work with various Klan and neo-Nazi groups in Texas, Arkansas, Louisiana, and Mississippi. Her work in the field began in January 2005 and ended in December 2012. She is interested in extremist social movements, white nationalist identity issues, home grown racist religions, and far right political activism. Address correspondence to: Dr. Dianne Dentice, Stephen F. Austin State University, 1936 North Street, Nacogdoches, TX 75962; e-mail: denticede@sfasu.edu.
} 